\title{
A unique case of venous anomalies in the situs solitus and normocardia
}

\author{
Ranko Zdravkovic ${ }^{1}$, Aleksandar Redzek ${ }^{1}$, Stamenko Susak $^{1}$, Jelena Vuckovic ${ }^{1}$, Miodrag \\ Golubovic $^{1}$, Dragan Lazarevic ${ }^{1}$, Mirko Todic $^{1}$, and Lazar Velicki ${ }^{1}$ \\ ${ }^{1}$ Institute of Cardiovascular Diseases of Vojvodina
}

September 24, 2020

\begin{abstract}
A persistent left superior vena cava is relatively common venous anomaly. But, the presence of persistent left superior vena cava with the atresia of the right superior vena cava is a much rarer situation. The association of these anomalies with the drainage of the left hepatic vein into the right atrium is an extremely rare situation. Here we present one such case in the situs solitus and normocardia.
\end{abstract}

\section{References}

1. Shoiab I, Schaff H, Saran N, Charnin J, Ritter M. Recommendations for Perioperative Management in Patients With Absent Right Superior Vena Cava. J Cardiothorac Vasc Anesth 2019;33(6):1710-1713.

2. Uraz S, Duran C, Balci D, et al. A very rare venous anomaly in a living liver donor: left hepatic venous connection to the right atrium. Transplant Proc 2007;39(5):1714-5.

Conflict of Interest: The authors declare that there are no conflict of interests.

Ethics statement: Informed consent was obtained in writing form from the patient.

\section{Hosted file}

Figure.pdf available at https://authorea.com/users/361483/articles/482882-a-unique-case-ofvenous-anomalies-in-the-situs-solitus-and-normocardia 